\title{
Changes of leaf antioxidant system, photosynthesis and ultrastructure in tea plant under the stress of fluorine
}

\author{
C. LI, Y. ZHENG, J. ZHOU, J. XU and D. NI* \\ College of Horticulture and Forestry Science, Huazhong Agricultural University; \\ Key Laboratory of Horticultural Plant Biology, Ministry of Education, \\ Shizishan Street, Wuhan 430070, P.R. China
}

\begin{abstract}
Seedlings of Camellia sinensis were grown hydroponically for $30 \mathrm{~d}$ in order to study the effect of fluorine (F) on growth parameters, antioxidant defence system, photosynthesis and leaf ultrastructure. Fresh and dry mass, chlorophyll (Chl) content and net photosynthetic rate $\left(\mathrm{P}_{\mathrm{N}}\right)$ decreased with increasing F concentration. Superoxide dismutase (SOD) activity decreased significantly, catalase (CAT) and guaiacol peroxidase (GPX) activities reached maximun under 0.21 and $0.32 \mathrm{mM} \mathrm{F}$, respectively. Proline, malondialdehyde (MDA) and hydrogen peroxide $\left(\mathrm{H}_{2} \mathrm{O}_{2}\right)$ contents increased significantly. These results suggested, that antioxidant defence system of leaves did not sufficiently scavenge excessive reactive oxygen species. The cell ultrastructure was not changed under $0.11-0.21 \mathrm{mM} \mathrm{F}$, however, it was destroyed at $0.32-0.53 \mathrm{mM}$ F. So tea plants tolerated F in concentration less than $0.32 \mathrm{mM}$.
\end{abstract}

Additional key words: catalase, Camellia sinensis, chloroplasts, guaiacol peroxidase, $\mathrm{H}_{2} \mathrm{O}_{2}$, malondialdehyde, net photosynthetic rate, proline, superoxide dismutase.

Fluorine, a phytotoxin in air, water, soil, and vegetation, is released into the environment from a number of industrial sources (Mackowiak et al. 2003), application of phosphate fertilizers in agriculture (Loganathan et al. 2001), and weathering of volcanic ashes (Cronin et al. 2003). F is transferred from soil to roots, and then to above ground parts, or absorbed by leaves from the air. The F content was reported to reach $871-1337 \mathrm{mg} \mathrm{kg}^{-1}$ (f.m.) in mature tea leaves, and even more than $2000 \mathrm{mg} \mathrm{kg}^{-1}$ (f.m.) in leaves of old tea plants (Ruan and Wong 2001, Shu et al. 2003). To our knowledge, little information is available regarding the effects of excessive $F$ on physiological functions in tea plant. In the present study, the changes of antioxidant defence system, photosynthesis and cell ultrastructure of tea leaves under $F$ stress were investigated, in order to study the mechanisms of tea plant F tolerance.
Camellia sinensis (L.) O. Kuntze cv. Fu Ding da Bai 1-year-old cuttings, provided by the Fruit and Tea Research Institute of Hubei Agricultural Academy, China, were planted in plastic pots containing $1.5 \mathrm{dm}^{3}$ of $1 / 2$ strength Hoagland nutrient solution (Hoagland and Arnon 1950). $\mathrm{F}$ (as $\mathrm{NH}_{4} \mathrm{~F}$ ) was supplied at five concentrations: 0 (control), 0.11, 0.21, 0.32, $0.53 \mathrm{mM}$. For each treatment, 5 pots (with 5 seedlings each) were used, and the pots were arranged in the glasshouse in random design. The liquid solutions ( $\mathrm{pH} 5.5)$ were ventilated with air pumps and replaced completely every $5 \mathrm{~d}$. The seedlings were cultivated for $30 \mathrm{~d}$ in a glasshouse under day/night temperature of $25 \pm 3 / 15 \pm 2{ }^{\circ} \mathrm{C}$ and irradiance, of $250-280 \mu \mathrm{mol} \mathrm{m} \mathrm{m}^{-2} \mathrm{~s}^{-1}$ during $16-\mathrm{h}$ photoperiod.

Fresh mass (f.m.) of the whole plant was determined immediately after harvesting. Dry mass (d.m.) of the whole plant was determined after drying at $80^{\circ} \mathrm{C}$ till

Received 6 December 2009, accepted 15 April 2010.

Abbreviations: CAT - catalase; Chl - chlorophyll; F - fluorine; GPX - guaiacol peroxidase; MDA - malondialdehyde; $\mathrm{P}_{\mathrm{N}}$ - net photosynthetic rate; SOD - superoxide dismutase; TEM - transmission electron microscope.

Acknowledgements: Authors are grateful to Prof. S.Y. Lan for his helpful suggestions and guidance in transmission electron microscope.

* Corresponding author; fax: (+86) 278728 0781, e-mail: nidj2009@gmail.com 
constant mass. Chlorophyll (Chl) content was measured in an $80 \%$ acetone extract spectrophotometrically at 663 and $645 \mathrm{~nm}$ as described by Jiang et al. (2007). Net photosynthetic rate $\left(\mathrm{P}_{\mathrm{N}}\right)$ was measured by TPS-1 photosynthesis system (PP Systems, Amesbury, MA, USA). The seedlings were put outdoors in the morning from 9:00 to 11:00. The photosynthesis of the $3^{\text {rd }}$ or $4^{\text {th }}$ leaf from the top was detected at irradiance of 800 to $900 \mu \mathrm{mol}$ $\mathrm{m}^{-2} \mathrm{~s}^{-1}, \mathrm{CO}_{2}$ concentration of 370 to $380 \mu \mathrm{mol} \mathrm{mol}^{-1}$, air temperature of $28 \pm 0.5{ }^{\circ} \mathrm{C}$ and relative humidity of $60 \pm 0.8 \%$. Three seedlings were measured in each treatment and repeated three times. Total $\mathrm{F}$ was tested with an ion selective electrode (Orion 9609BNWP with Orion $\mathrm{pH} / \mathrm{ISE}$ meter 710, both Thermo Scientific, Waltham, MA, USA). The leaves were oven-dried at $80{ }^{\circ} \mathrm{C}$ for $24 \mathrm{~h}$, and then ground to pass through a $2-\mathrm{mm}$ sieve. The grounded sample $(0.2 \mathrm{~g})$ was extracted with $10 \mathrm{~cm}^{3}$ of $0.2 \mathrm{M} \mathrm{HCl}$ at room temperature for $1 \mathrm{~h}$. After filtration, $25 \mathrm{~cm}^{3}$ total ionic strength adjustment buffer (TISAB) was added. Finally, the volume was fixed to $100 \mathrm{~cm}^{3}$ with super-pure water produced by a purification system (Millipore, Bedford, MA, USA).

For enzyme extraction, fresh leaves $(0.5 \mathrm{~g})$ were ground on ice with $0.5 \mathrm{~g}$ quartz sands and $5 \mathrm{~cm}^{3}$ of $50 \mathrm{mM}$ precooled phosphate buffer $(\mathrm{pH} 7.8)$ containing $1 \mathrm{mM}$ ethylenediaminetetracetic acid (EDTA) and $5 \%(\mathrm{~m} / \mathrm{v})$ polyvinylpyrrolidone (PVP). The homogenate was centrifugated $(16000 \mathrm{~g})$ at $4{ }^{\circ} \mathrm{C}$ for $15 \mathrm{~min}$. Then the supernatant was used for superoxide dismutase (SOD; E.C.1.15.1.1), catalase (CAT; E.C.1.11.1.6) and guaiacol peroxidase (GPX; E.C1.11.1.7) analysis (Pereira et al. 2002). The activity of total SOD, Cu/Zn-SOD, Mn-SOD and CAT were determined by using the reagent kit (Nanjing Jiancheng Bioengineering institute, Nanjing, China). The GPX was determined by modified guaiacol method. $0.1 \mathrm{~cm}^{3}$ of enzyme solution, $0.9 \mathrm{~cm}^{3}$ of $2 \%$ guaiacol and $1.0 \mathrm{~cm}^{3}$ of $0.3 \% \mathrm{H}_{2} \mathrm{O}_{2}$ were added into $1.0 \mathrm{~cm}^{3}$ of potassium phosphate buffer $(\mathrm{pH}$ 5.7), following absorbance variation at $470 \mathrm{~nm}$ within $5 \mathrm{~min}$ (Ramiro et al. 2006).

Proline content in the leaves was measured by acidic ninhydrin method according to Khedr et al. (2003). The content of malondialdehyde (MDA) in the leaves was measured by thiobarbituric acid (TBA) method according to Dhindsa et al. (1981). The $\mathrm{H}_{2} \mathrm{O}_{2}$ content in the leaves was measured according to Patterson et al. (1984).

For transmission electron microscope (TEM) analysis, the middle sections of the third leaves were cut $(1 \times 1 \mathrm{~mm})$, and then put into the fixation solution composed of $2.5 \%$ glutaraldehyde at $\mathrm{pH} 7.4$ immediately to make the samples sunk. The samples were fixed in $1 \% \mathrm{OsO}_{4}$ for $2 \mathrm{~h}$, dehydrated by acetone, embedded with epoxy resin (SPI-812) for $24 \mathrm{~h}$, and sliced up by ultramicrotone (UC6, Leica Microsystems, Wetzlar, Germany). The sections were stained with a mixture of lead citrate and uranyl acetate. Finally the configuration of cells was checked using TEM (H-7650, Hitachi, Tokyo, Japan) and photographed with Gatan 832 digital imaging system (Gatan, Pleasanton, USA).

All statistical analyses were done using the statistical package of the SAS software computer program. ANOVA followed by LSD test were carried out to test the significance.

SODs are ubiquitous metalloenzymes that play a role in defense against toxic reduced oxygen species. $\mathrm{Cu} / \mathrm{Zn}$-SODs are found throught the plant cell, existing in both chloroplastic and cytosolic forms; Mn-SODs are located in mitochondria and also in peroxisomes (Attia et al. 2008). Our data showed that the activity of total SOD, $\mathrm{Cu} / \mathrm{Zn}-\mathrm{SOD}$ and $\mathrm{Mn}-\mathrm{SOD}$ all decreased significantly $(P<0.01)$ with increasing $\mathrm{F}$ concentration (Table 1). The result is consistent with the findings of Wilde and $\mathrm{Yu}$

Table 1. The whole plant fresh and dry masses, F, Chl, proline, $\mathrm{H}_{2} \mathrm{O}_{2}$ and MDA contents, $\mathrm{P}_{\mathrm{N}}$, and activities of antioxidative enzymes in leaves of tea cultivated in a half strength Hoagland nutrient solution with $0,0.11,0.21,0.32$ or $0.53 \mathrm{mM} \mathrm{F}$ for $30 \mathrm{~d}$. Means $\pm \operatorname{SD}(n=3)$. Different letter in each row represents significant differences at $P<0.05$, based on LSD's multiple range test.

\begin{tabular}{|c|c|c|c|c|c|}
\hline Parameters & 0 & 0.11 & 0.21 & 0.32 & 0.53 \\
\hline Fresh mass [g plant $\left.{ }^{-1}\right]$ & $5.51 \pm 0.08 \mathrm{a}$ & $5.49 \pm 0.04 a$ & $5.28 \pm 0.1 b$ & $4.90 \pm 0.09 \mathrm{c}$ & $4.58 \pm 0.09 \mathrm{~d}$ \\
\hline Dry mass $\left[\mathrm{g} \mathrm{plant}^{-1}\right]$ & $1.72 \pm 0.03 a$ & $1.67 \pm 0.03 \mathrm{a}$ & $1.57 \pm 0.04 b$ & $1.45 \pm 0.02 \mathrm{c}$ & $1.33 \pm 0.04 \mathrm{~d}$ \\
\hline $\mathrm{F}$ content $\left[\mathrm{mg} \mathrm{kg}^{-1}\right.$ (d.m.) $]$ & $1283 \pm 16 a$ & $1525 \pm 6 b$ & $1702 \pm 15 c$ & $1763 \pm 20 \mathrm{~d}$ & $1876 \pm 14 \mathrm{e}$ \\
\hline Chl content $\left[\mathrm{mg} \mathrm{g}^{-1}\right.$ (f.m.) $]$ & $2.21 \pm 0.02 \mathrm{a}$ & $2.26 \pm 0.01 \mathrm{a}$ & $2.15 \pm 0.03 b$ & $1.99 \pm 0.04 c$ & $1.86 \pm 0.03 \mathrm{~d}$ \\
\hline $\mathrm{P}_{\mathrm{N}}\left[\mu \mathrm{mol} \mathrm{m} \mathrm{m}^{-2} \mathrm{~s}^{-1}\right]$ & $12.70 \pm 0.16 \mathrm{a}$ & $13.30 \pm 0.26 a$ & $10.70 \pm 0.36 b$ & $8.60 \pm 0.70 c$ & $3.90 \pm 0.16 \mathrm{~d}$ \\
\hline Total SOD [U g ${ }^{-1}$ (f.m.)] & $3191 \pm 46 a$ & $3084 \pm 22 b$ & $2899 \pm 25 c$ & $2818 \pm 52 c$ & $2639 \pm 64 d$ \\
\hline $\mathrm{Cu} / \mathrm{Zn}-\mathrm{SOD}\left[\mathrm{U} \mathrm{g}^{-1}\right.$ (f.m.)] & $2314 \pm 34 a$ & $2239 \pm 113 a$ & $2109 \pm 67 b$ & $2091 \pm 46 b$ & $1934 \pm 45 c$ \\
\hline Mn-SOD [U g ${ }^{-1}$ (f.m.) $]$ & $918 \pm 66 a$ & $921 \pm 32 \mathrm{a}$ & $806 \pm 47 b$ & $711 \pm 12 \mathrm{c}$ & $705 \pm 58 \mathrm{c}$ \\
\hline CAT $\left[\mathrm{U} \mathrm{g}^{-1}\right.$ (f.m.)] & $380 \pm 13 \mathrm{c}$ & $430 \pm 11 b$ & $447 \pm 7 \mathrm{a}$ & $395 \pm 11 \mathrm{c}$ & $358 \pm 22 d$ \\
\hline $\operatorname{GPX}\left[\mathrm{U} \mathrm{g}^{-1} \cdot \mathrm{min}^{-1}\right]$ & $1143 \pm 28 \mathrm{c}$ & $1149 \pm 70 \mathrm{c}$ & $1274 \pm 34 b$ & $1514 \pm 5 a$ & $1206 \pm 50 \mathrm{c}$ \\
\hline Proline $\left[\mu \mathrm{g} \mathrm{g}^{-1}\right.$ (f.m.) $]$ & $22.66 \pm 1.54 \mathrm{c}$ & $30.68 \pm 1.72 b$ & $32.91 \pm 1.37 \mathrm{~b}$ & $48.39 \pm 1.03 a$ & $49.73 \pm 0.74 a$ \\
\hline $\mathrm{H}_{2} \mathrm{O}_{2}\left[\mu \mathrm{mol} \mathrm{g} \mathrm{g}^{-1}\right.$ (f.m.) $]$ & $29.08 \pm 1.60 c$ & $30.18 \pm 0.63 b c$ & $33.20 \pm 0.81 \mathrm{ab}$ & $36.08 \pm 2.39 a$ & $36.65 \pm 2.22 \mathrm{a}$ \\
\hline MDA [nmol g ${ }^{-1}$ (f.m.)] & $6.56 \pm 0.51 \mathrm{c}$ & $6.69 \pm 0.57 \mathrm{c}$ & $8.15 \pm 0.02 b$ & $10.35 \pm 0.49 a$ & $10.30 \pm 0.26 \mathrm{a}$ \\
\hline
\end{tabular}




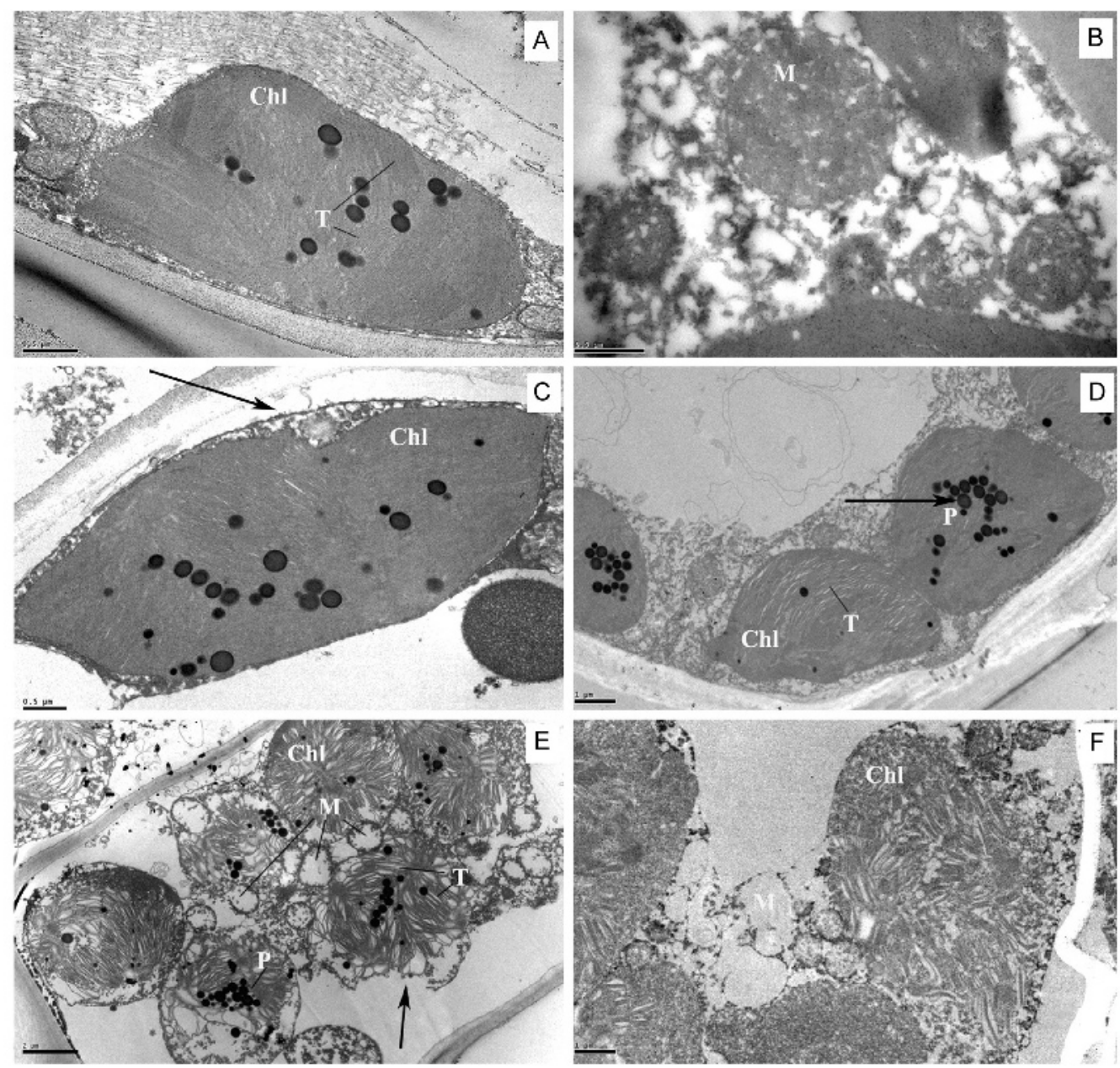

Fig. 1. Leaf ultrastructure of tea seedlings grown under $0 \mathrm{mM}$ (control, $A, B), 0.11 \mathrm{mM}(C), 0.21 \mathrm{mM}(D), 0.32 \mathrm{mM}(E)$ and $0.53 \mathrm{mM}(F)$ fluorine for $30 \mathrm{~d}$, respectively. Bars $=0.5 \mu \mathrm{m}(A, B, C), 1 \mu \mathrm{m}(D, F)$ and $2 \mu \mathrm{m}(E)$, respectively. $A$ - chloroplast was elliptical and thylakoids were arranged closely and aligned in an orderly manner; $B$ - mitochondria were intact, with complete membrane structure and clear cristae; $C$ - the plasmolysis observed at $0.11 \mathrm{mM} \mathrm{F}$ treatment; $D$ - the plastoglobulus increased (arrow) and thylakoids expanded slightly at $0.21 \mathrm{mM} \mathrm{F}$ treatment; $E$ - the shape of chloroplast changed, membrane was ruptured (arrow), the system of the membranes was obliterated, mitochondria were cavitated completely; $F$ - chloroplasts and thylakoids were disintegrated, and mitochondria degraded. Chl - chloroplast, $\mathrm{T}$ - thylakoid, $\mathrm{M}$ - mitochondria, P - plastoglobulus.

(1998). CAT and GPX activities increased at low $\mathrm{F}$ concentrations, reached their peaks when the F concentrations were 0.21 and $0.32 \mathrm{mM}$, respectively, and decreased at higher concentrations (Table 1). Generally, antioxidant enzymes and non-enzymatic antioxidants including proline have synergistic effects on free radical scavenging, thus the generation and removal of free radical is balanced (Mascher et al. 2002, Tasgín et al. 2003). However, the reduced activity of antioxidant enzymes under stressed condition can lead to lipid peroxidation and membrane damage (Scandalios 2005). The content of MDA, a product of peroxidation of membrane lipids, is often used as an indicator of oxidative damage (Gunes et al. 2007). In the present study, MDA and $\mathrm{H}_{2} \mathrm{O}_{2}$ contents increased significantly (Table 1). Accumulation of $\mathrm{H}_{2} \mathrm{O}_{2}$ and lipid peroxidation resulted in a significant decrease in cell membrane stability. TEM also proved it, e.g. membranes of chloroplasts were ruptured (Fig. 1E). These results suggested that antioxidants did not sufficiently scavenge excessive reactive oxygen species to protect the tissue from free radical injury under the F stress.

The related research had proved that the increase of proline was a common response of most plants to environmental stress (Almansouri et al. 1999, Meloni et al. 2001). In addition to osmotic adjustment (Tripathi and Gaur 2004), proline also stabilizes cellular structures and acts as a free radical scavenger (Alia and Matysik 2001, Siripornadulsil et al. 2002). In this trial, proline content increased remarkably $(P<0.01)$. Significant increase in proline content has been reported earlier in tea under $\mathrm{Cu}^{2+}$ and $\mathrm{Al}^{3+}$ stress (Yadav and Mohanpuria 2009).

Based on the results of TEM, it was discovered that cell ultrastructure changed little under $0.11-0.21 \mathrm{mM} \mathrm{F}$, but an irreversible destruction under the concentration of $\mathrm{F}$ 
higher than $0.32 \mathrm{mM}$ was observed. Under high F stress, chloroplast damage, such as membrane rupture, thylakoid expantion (Fig $1 E$ ) and even disintegration (Fig $1 F$ ) was found, which would strongly influence the photosynthesis. In present study, both $\mathrm{Chl}$ content and $\mathrm{P}_{\mathrm{N}}$ increased slightly at low $F$ concentration $(0.11 \mathrm{mM})$ but not significantly. However, these two parameters decreased significantly $(P<0.05)$ with increasing $\mathrm{F}$ concentration. The high electronegativity of $\mathrm{F}$ destroyed the Chl molecule and accelerated disintegration of chloroplasts

\section{References}

Aboal, J., Couto, J., Fernández, J., Carballeira, A.: Physiological responses to atmospheric fluorine pollution in transplants of Pseudoscleropodium purum. - Environ. Pollut. 153: 602-609, 2008.

Alia, M., Matysik, J.: Effect of proline on the production of singlet oxygen. - Amino Acids 21: 195-200, 2001.

Almansouri, M., Kinet, J., Lutts, S.: Compared effects of sudden and progressive impositions of salt stress in three durum wheat (Triticum durum Desf.) cultivars. - J. Plant Physiol. 154: 743-752, 1999.

Attia, H., Arnaud, N., Karray, N., Lachaal, M.: Long-term effects of mild salt stress on growth, ion accumulation and superoxide dismutase expression of Arabidopsis rosette leaves. - Physiol. Plant. 132: 293-305, 2008.

Cronin, S., Neall, V., Lecointre, J., Hedley, M., Loganathan, P.: Environmental hazards of fluoride in volcanic ash: a case study from Ruapehu volcano. - New Zeal. J. Volcanology Geothermal Res. 121: 271-291, 2003.

Dhindsa, R., Pluma-Dhindsa, P., Thorpe, T.: Leaf senescence: correlated with increased levels of membrane permeability and lipid peroxidation, and decreased levels of superoxide dismutase and catalase. - J. exp. Bot. 32: 93-101, 1981.

Fornasiero, R.: Phytotoxic effects of fluorides. - Plant Sci. 161: 979-985, 2001

Gunes, A., Inal, A., Bagci, E., Coban, S., Sahin, O.: Silicon increases boron tolerance and reduces oxidative damage of wheat grown in soil with excess boron. - Biol. Plant. 51: 571-574, 2007.

Hoagland, D., Arnon, D.: The water culture method for growing plants without soil. - California Agr. Exp. Sta. Circular 347: 1-32, 1950.

Jiang, H., Yang, J., Zhang, J.: Effects of external phosphorus on the cell ultrastructure and the chlorophyll content of maize under cadmium and zinc stress. - Environ. Pollut. 147: 750-756, 2007.

Khedr, A., Abbas, M., Wahid, A., Quick, W., Abogadallah, G.: Proline induces the expression of salt-stress-responsive proteins and may improve the adaptation of Pancratium maritimum L. to salt-stress. - J. exp. Bot. 54: 2553-2562, 2003.

Loganathan, P., Hedley, M., Wallace, G., Roberts, A.: Fluoride accumulation in pasture forages and soils following long-term applications of phosphorus fertilisers. - Environ. Pollut. 115: 275-282, 2001.
(Fornasiero 2001, Aboal et al. 2008).

In conclusion, exposure of tea seedlings to $\mathrm{F}$ decreased fresh mass, dry mass, $\mathrm{Chl}$ content and $\mathrm{P}_{\mathrm{N}}$, increased MDA, proline and $\mathrm{H}_{2} \mathrm{O}_{2}$ contents and changed SOD, POX, CAT activities. It is suggested that antioxidant defence system did not sufficiently protect the tissue under severe F stress. This was confirmed by the damage of cell ultrastructure. Tea plants are able tolerate $\mathrm{F}$ in concentration less than $0.32 \mathrm{mM}$.

Mackowiak, C., Grossl, P., Bugbee, B.: Biogeochemistry of fluoride in a plant-solution system. - J. environ. Quality 32: 2230-2237, 2003.

Mascher, R., Lippmann, B., Holzingers, S., Bergmann, H.: Arsenate toxicity: effects on oxidative stress response molecules and enzymes in red clover plants. - Plant Sci. 163: 961-969, 2002.

Meloni, D., Oliva, M., Ruiz, H., Martinez, C.: Contribution of proline and inorganic solutes to osmotic adjustment in cotton under salt stress. - J. Plant Nutr. 24: 599-612, 2001.

Patterson, B., MacRae, E., Ferguson, I.: Estimation of hydrogen peroxide in plant extracts using titanium (IV). - Anal. Biochem. 139: 487, 1984.

Pereira, G., Molina, S., Lea, P., Azevedo, R.: Activity of antioxidant enzymes in response to cadmium in Crotalaria juncea. - Plant Soil 239: 123-132, 2002.

Ramiro, D., Guerreiro-Filho, O., Mazzafera, P.: Phenol contents, oxidase activities, and the resistance of coffee to the leaf miner Leucoptera coffeella. - J. chem. Ecol. 32: 1977-1988, 2006.

Ruan, J., Wong, M.: Accumulation of fluoride and aluminium related to different varieties of tea plant. - Environ. Geochem. Health 23: 53-63, 2001.

Scandalios, J.: Oxidative stress: molecular perception and transduction of signals triggering antioxidant gene defenses. - Braz. J. med. biol. Res. 38: 995-1014, 2005.

Shu, W., Zhang, Z., Lan, C., Wong, M.: Fluoride and aluminium concentrations of tea plants and tea products from Sichuan Province, PR China. - Chemosphere 52: 1475-1482, 2003.

Siripornadulsil, S., Traina, S., Verma, D., Sayre, R.: Molecular mechanisms of proline-mediated tolerance to toxic heavy metals in transgenic microalgae. - Plant Cell 14: 2837-2847, 2002.

Taşgín, E., Atící, Ö., Nalbantoğlu, B.: Effects of salicylic acid and cold on freezing tolerance in winter wheat leaves. - Plant Growth Regul. 41: 231-236, 2003.

Tripathi, B., Gaur, J.: Relationship between copper-and zinc-induced oxidative stress and proline accumulation in Scenedesmus sp. - Planta 219: 397-404, 2004.

Wilde, L., Yu, M.: Effect of fluoride on superoxide dismutase (SOD) activity in germinating mung bean seedlings. Fluoride 31: 81-88, 1998.

Yadav, S., Mohanpuria, P.: Responses of Camellia sinensis cultivars to $\mathrm{Cu}$ and $\mathrm{Al}$ stress. - Biol. Plant. 53: 737-740, 2009. 